\title{
Signal Transduction in Immune Cells and Protein Kinases
}

\author{
Monica Neagu and Carolina Constantin
}

\section{Abstract}

Immune response relies upon several intracellular signaling events. Among the protein kinases involved in these pathways, members of the protein kinase $\mathrm{C}$ (PKC) family are prominent molecules because they have the capacity to acutely and reversibly modulate effector protein functions, controlling both spatial distribution and dynamic properties of the signals. Different PKC isoforms are involved in distinct signaling pathways, with selective functions in a cell-specific manner.

In innate system, Toll-like receptor signaling is the main molecular event triggering effector functions. Various isoforms of PKC can be

The original version of this chapter was revised. The correction to this chapter is available at https://doi.org/10.1007/978-3-030-49844-3_17

M. Neagu

Immunology Department, Victor Babes National Institute, Bucharest, Romania

Faculty of Biology, University of Bucharest, Bucharest, Romania

Colentina University Clinical Hospital,

Bucharest, Romania

C. Constantin $(\square)$

Immunology Department, Victor Babes National Institute, Bucharest, Romania

Colentina University Clinical Hospital,

Bucharest, Romania common to different TLRs, while some of them are specific for a certain type of TLR. Protein kinases involvement in innate immune cells are presented within the chapter emphasizing their coordination in many aspects of immune cell function and, as important players in immune regulation.

In adaptive immunity T-cell receptor and B-cell receptor signaling are the main intracellular pathways involved in seminal immune specific cellular events. Activation through TCR and BCR can have common intracellular pathways while others can be specific for the type of receptor involved or for the specific function triggered. Various PKC isoforms involvement in TCR and BCR Intracellular signaling will be presented as positive and negative regulators of the immune response events triggered in adaptive immunity.

\section{Keywords}

Adaptive immune cells · Innate immune cells · Protein kinase $\cdot$ Intracellular signaling

\section{Introduction}

Cells of the immune system whether appending to the innate or acquired arm undergo complex processes starting from their development 
through their maturation and effective action displayed on the aggressor that triggered an immune response (Neagu 2012). Immune cellular responses activated by external and/or internal cues are governed by complex networks of signal transduction pathways. These intracellular pathways have as crucial regulators protein kinases.

Isoforms of Protein kinase C (PKC) span the entire panel of immune cells and are involved in seminal immune processes. PKC families are enzymes involved in signaling pathways. Their action is to specifically phosphorylate substrates at serine/threonine aminoacids. Through this action PKCs regulate important cellular events like cell proliferation, differentiation, immune response and so on. PKCs consist of 10 kinase members. They have a highly catalytic kinase domain that is structurally conserved and a regulatory domain with a less conserved structure (Lim et al. 2015).

In $\mathrm{T}$ lymphocyte regulation, there are different $\mathrm{PKC}$ isoforms with various physiological roles and non-redundant functions. Just to enumerate some of the PKCs, PKC $\theta$ and $\mathrm{PKC} \alpha$ isoforms are involved in antigen-induced $\mathrm{T}$ cell activation, inhibition of $\mathrm{T}$ cell-mediated responses and in important pathological processes like allograft rejection and autoimmunity. Regulation of $\mathrm{T}$ cell proliferation and cell cycle progression have as key molecules distinct PKC isoforms that play positive roles during cell cycle progression, but there are also isoforms like PKC $\delta$ which serves as regulators.

$B$ cells are activated after antigen binding to $B$ cell receptor (BCR) that needs for intracellular signaling CD79 molecules. In B cells pathways involving $\mathrm{PKC} \beta$ are triggered. One common intracellular pathway with TCR signaling is the CARD11-BCL10-MALT1 (CBM) signalasome complex activating in the end the nuclear NFkB.

Innate immune system detects pathogens through Toll-like receptors (TLRs), receptors that recognize specific molecular patterns expressed by the aggressors. Different TLRs would lead to various gene expressions, and would recognize different components of microorganisms. In the intracellular signaling events triggered upon TLR activation various common or less common PKC isoforms are involved (Akira and Takeda 2004).

\subsection{PKCs Traits}

In the signal transduction pathway the extracellular signal that is considered the first messenger will be converted in another intracellular signal that will be the second messenger and this conversion is done at the plasma membrane. Further molecular conversions in the intracellular signaling events will take place in the cytoplasm, at organelle membranes like the nuclear envelope, and finally inside the nucleus. The main protein kinase (PK) in the immune system signaling is PKC because it can be activated by $G$ proteins that are coupled to receptors and tyrosine kinase receptors, so that upon activation it can generate an array of intracellular signals. Activation of various isoforms of phospholipase C (PLC) generates diacylglycerol (DAG) and inositol phosphate 3 (IP3), both of them activating PKC (Nishizuka 1995). IP3 will induce the release of $\mathrm{Ca}^{2+}$ from intracellular stores that will activate certain PKC sub-families. The "immunological synapse" developed between specific $\mathrm{T}$ cell receptors (TCR) and the antigen presenting cell (APC) resides in the activation of PKC triggering the intracellular cascade as a response to a stimulus from the plasma membrane to the nucleus. Interestingly PKCs were found as transducer within the nucleus, pathway different from the cytoplasmic signalling event directly regulating gene expression (Lim et al. 2015). In the journey to develop the nucleus-driven intracellular signaling pathway PKC can trigger MAPK (mitogen-activated protein kinase) cascade by activating Raf (Rapidly Accelerated Fibrosarcoma). Also cytoplasmic PKC, when activated will phosphorylate the inhibitor of transcripiton factor nuclear factor (NF) kB (IkB). The phosphorylation will induce the proteolytic degradation of the inhibitor so that NFkB will translocate to the nucleus (Baeuerle and Henkel 1994).

Without being exhaustive, this chapter will highlight some aspects regarding PKC isoforms 
involved in intra-cytoplasmatic signaling events that are involved in the development of the immune response whether triggered by innate or adaptive immune cells.

\section{$2 \quad$ Toll-Like Receptor Signaling in the Innate System}

The innate immune system arm has numerous first line defense functions, one of these functions engages the initial detection of microbes through pattern recognition receptors (PRRs). PRRs will recognize the specific microbe molecular pattern, pathogen-associated molecular patterns (PAMPs). PRRS can recognize also structures that result from damaged cells, damage associated molecules patterns (DAMPs). When activated PRRs will activate intracellular signaling pathways that will further induce complex immune responses by activating the synthesis of inflammatory cytokines, e.g. type I interferon (IFN), and an array of several other immune mediators. This initial activation initiates inflammation, and primes further antigen-specific adaptive immune responses. These orchestrated responses has as final scope the clearance of infecting microbes and the instruction of adaptive immune responses that is antigen-specific (Janeway $\mathrm{Jr}$ and Medzhitov 2002). Amidst the signaling pathways, the family of PKCs appending to the larger family of protein serine / threonine kinases keeps the central role in intracellular signal transduction.

Discovered more than 15 years ago PKCs comprises isoforms that are divided in 3 subfamilies: PKC- $\alpha, \beta \mathrm{I},-\beta \mathrm{II}$, and $-\gamma$; PKC- $\delta,-\varepsilon$, $-\eta$, and $-\theta$, and the atypical subfamily, PKC $\zeta$ and $\lambda / \imath$. These 3 sub-families were divided as such due to their characteristics, thus the first mentioned sub-family requires calcium, DAG, and phosphatidylserine (PS); the second subfamily requires DAG and PS in a calciumindependent manner and the last sub-family requires only PS (Newton 2003). As PKC with its various isoforms are involved in cell proliferation, differentiation, apoptosis, and motility these enzymes have been discovered as being involved in various disease from cancer to cardiovascular disease (Churchill et al. 2008; Ali et al. 2009; Palaniyandi et al. 2009; Gonelli et al. 2009; Bynagari-Settipalli et al. 2010). TLRs are actually the family of receptors that will recognize PRRS and DAMPs to trigger an effective innate immune response (Gay and Gangloff 2007; Kawai and Akira 2010). PKCs are involved in several intracellular signaling events induced by TLRs. Molecular events triggered from various TLRs differ, but the process is generally initiated after recruiting TIR (Toll/IL-1 Receptor homology) containing adaptor proteins [e.g. TIRAP (TIR Adaptor Protein) would recruit MyD88 (myeloid differentiation factor 88), TRAM (TRIF-related adaptor molecule) would recruit TRIF (TIR-domain-containing adapterinducing interferon- $\beta$ )]. Thereafter MyD88 would recruit IRAK 1,2,4 (IL-1R-associated kinase) and TRAF6 (tumor necrosis factor receptor-associated factor-6). This event would induce finally the pro-inflammatory genes activation. TLR binding to TRIF would recruit TRAF6, $\beta$ RIP1 (Receptor-interacting serine/ threonine-protein kinase 1), and TAK1 (TGF- $\beta$ activated kinase) and finally induce interferon- $\beta$ (IFN) genes. The activation of TRIF pathway induces the pro-inflammatory cytokines secretion but to a lesser extent than MyD88 pathway. The involvement of various PKC isoforms in TLR signaling was proven when altering PKC enzyme activity within innate immune cells, the process of cytokine secretion was deregulated. Moreover, various TLR ligands activate different PKC isoforms in all innate immune cells, e.g. monocytes, macrophages, dendritic cells and neutrophils (Fronhofer et al. 2006; Zhou et al. 2006; Asehnoune et al. 2005). These PKC isoforms are expressed different in monocytes and macrophages, being involved also in monocyte differentiation. PKC $\alpha$ and $\beta$ are activated during stimulation and monocyte-/ macrophage-induced differentiation while PKC $\delta$ expression decreases. Parihar et al. have shown that PKCס links and phosphorylates caspase-3, inducing an increase in the apoptotic activity (Parihar et al. 2010). In neutrophils PKC $\delta$ activation downstream of dectin- 1 and Mac- 1 is 
involved in the antifungal action but not the function of macrophages ( $\mathrm{Li}$ et al. 2016). In dendritic cells (DC) PKC- $\beta$ expression and signaling is important in inducing DC differentiation (Cejas et al. 2005). It was also reported that as DCs are involved in induction of chronic inflammatory diseases (Joffre et al. 2012) PKCs regulate caspase-3-dependent apoptosis (Alcain et al. 2017).

In the signaling pathways of TLRs there are common molecules, but also specific ones. Thus MyD88-dependent intracellular signaling event is used by all TLRs except for TLR3. MyD88dependent intracellular pathways activates MAPKK (mitogen-activated protein kinase kinase) and IKK (IKB kinase) complex inducing the nuclear translocation of AP-1 (Activator Protein 1) and NF- $\kappa \mathrm{B}$ (nuclear factor kappa-lightchain-enhancer of activated B-cells). TRIF is the principal adaptor protein in the MyD88independent events and can assembly with TRAF6 to activate AP-1 and NF- $\kappa$ B (Patel et al. 2012).

An overview of the major intracellular events where PKCs are involved in TLRs signaling is presented in Fig. 5.1 and some details regarding the involvement of PKC $\alpha, \delta$ and $\varepsilon$ in the TLR signaling events are further presented.

\subsection{PKC Isoforms Involved in TLR Signaling}

\subsubsection{PKC- $\alpha$}

This is one of the conventional isoforms first discovered by using inhibitors that were inhibiting cytokine secretion in macrophages stimulated via TLR (Loegering and Lennartz 2011; Foeyand and Brennan 2004; Catley et al. 2004). Several other studies have shown the link between PKC- $\alpha$ and TLR-related functions. Thus, earlier studies have shown that 264.7 RAW macrophages with low expression of PKC- $\alpha$ have also TNF- $\alpha$, IL-1 $\beta$, iNOS, and NF-IL6 (CAAT/enhancer-binding protein $\beta$ ) low secretion upon LPS-activation (Chano and Descoteaux 2002). Moreover the lack of PKC- $\alpha$ is associated with deregulated phagocytosis, low killing capacity of pathogens, all these functions being non-TLR-related innate immunity responses (Ng Yan Hing et al. 2004; Holm et al. 2003). PPAR $\gamma$ regulates phorbol ester-induced NF- $\kappa \mathrm{B}$ activation and TNF- $\alpha$ synthesis/secretion by hindering the activation of PKC- $\alpha$ (von Knethen et al. 2007). More recent studies, have shown in human DCs that PKC- $\alpha$ inhibition blocks also the IL-12p40 secretion that was induced by the activation of TLR $2 / 6$, TLR 2/1, TLR5, but not through TLR3 (Langlet et al. 2010). DCs from mice with the phenotype PKC$\alpha-/-$ need PKC- $\alpha$ activation for TLR2/1activation of MAPK, NF- $\mathrm{KB}$ and AP-1; activation that would lead to the secretion of TNF $\alpha$, IL-6 and IL-10 (Langlet et al. 2010). In an earlier study, Johnson et al. found that a TLR3 ligand can activate PKC- $\alpha$. Hence, silencing PKC- $\alpha$ with siRNA, TLR3-stimulated IFN- $\beta$ production was blocked in DCs. After silencing the PKC $\alpha$ no hindering of IRF3 activation was recorded but the IRF-3 transcriptional activity was inhibited when induced by TRIF and TBK1 (TANKbinding kinase 1) over-expression. Probably this effect is the consequence of the decreased IRF-3 binding to $\mathrm{CBP}$ that needs PKC- $\alpha$ activation (Johnson et al. 2007).

\subsubsection{PKC- $\delta$}

In innate immune cells, TLR-related cytokine secretion involves the activation of $\mathrm{PKC}-\delta$; this assertion was sustained by the fact that its inhibition decreases the activation of NF- $\kappa \mathrm{B}$, reduces the inflammatory cytokines secretion and the production of nitric oxide (Bhatt et al. 2010; Ikewaki et al. 2007). PKC- $\delta$ interacts with TIRAP via the TIR domain during TLR signaling process (Kubo-Murai et al. 2007). If $\mathrm{PKC}-\delta$ is depleted, the kinase activity in the complexed TIRAP is lost prooving that $\mathrm{PKC}-\delta$ is the major kinase within TIRAP complex. In cecal ligation and puncture (CLP) animal model for sepsis, TLR signaling was studied in vivo. A PKC- $\delta$ inhibiting peptide was administered intra-tracheally in this model and the administration reduced the lung injury blocking sepsis-induced phosphorylation of this PKC- $\delta$ isoform. In this experimental model reduced levels of various chemokines were obtained, reduced inflammatory cells infiltration in the lungs and lower pul- 
Fig. 5.1 TLR signaling main pathways. PKCs various isoforms can be found at various levels and appending to various TLR types. TLR2 after activation would associate with $\mathrm{PKC} \alpha . \mathrm{PKC} \alpha$ is also involved in the TLR3 signaling, namely binding to the IRF3 CBP complex (Interferon Regulatory Factor-CREB Binding Protein) and hence inducing the activation of IFN- $\beta$ gene. PKC $\varepsilon$ is needed for TLR2/4 activation, as involved in TRAM phosphorylation. Activation of NFkB needs PKC- $\delta$. PKC- $\zeta$ is also needed for TLR $2 / 4$ activation when it associates to TRAF6 and RhoA (Ras homolog gene family, member A) for transcription of p65 (nuclear factor NF-kappa-B p65 subunit). While both nuclear activation pathways induce Type I IFN $\gamma$, only CBP-p65 pathway induces IL-1, IL-6, TNF $\alpha$

\section{TLRs}

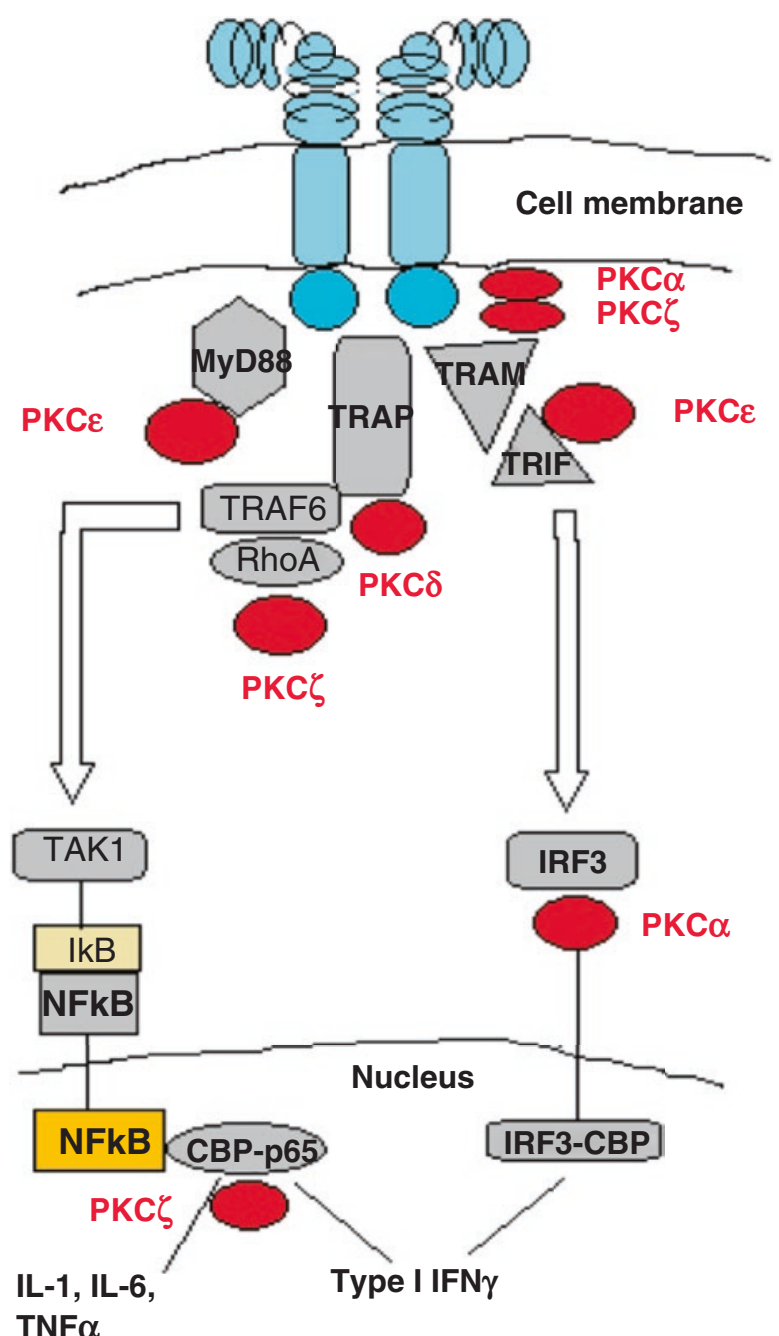

Cytokines monary edema. All these tissue effects were attributed to macrophages, endothelial cells, and epithelial cells (Kilpatrick et al. 2011).

In activated macrophages, PKC- $\delta$ is positioned downstream of Sphingosine kinase 1 (SphK1) activation being required for NF- $\mathrm{KB}$ activation. In vivo inhibiting SphK1 reduced sepsis-stimulated cytokine secretion and mortality in animal models. This isoform is a link in the activation chain TLR4-SphK1-PKC- $\delta$-NF- $\kappa B-$ cytokine release (Snider et al. 2010).

\subsubsection{PKC- $\varepsilon$}

The first study showing PKCE involvement in innate immunity-related events was reported almost 20 years ago by Castrillo et al. when PKC- $-\varepsilon-/-$ mice had spontaneous infections of the uterus and decreased survival rate upon experimental infection (Castrillo et al. 2001). Further studies that have used PKC- $\varepsilon$ specific inhibitors, have shown in the same PKC- $-1-/-$ mouse model that PKC- $\varepsilon$ is seminal for LPSstimulated TNF- $\alpha$ and IL- 12 secretion performed by DC and macrophages (Comalada et al. 2003; 
Koyanagi et al. 2007). This experiment reinforced the involvement of PKC- $\varepsilon$ in inflammation and host defense (Aksoy et al. 2004). Actually PKC- $\varepsilon$ is phosphorylated by all TLRs that need MyD88 (e.g. TLR1 - 9 except TLR3 in macrophages) (Faisal et al. 2008). If PKC- $\varepsilon$ can be phosphorylated also by PKC- $\alpha$, the effects of PKC- $\alpha$ on cytokine secretion can be shared by PKC- $\varepsilon$ (Saurin et al. 2008; Durgan et al. 2008). Moreover, PKC- $\varepsilon$ is involved in TLR4 activation but via TRAM pathway that induces IFN- $\beta$ and RANTES (Regulated on Activation Normal $\mathrm{T}$ Cell Expressed and Secreted). Recombinant PKC- $\varepsilon$, phosphorylates TRAM, but this phosphorylation does not appear in $\mathrm{PKC}-\varepsilon-/-$ cells with reduced production of IFN- $\beta$. Thus, actually PKC- $\varepsilon$ is a link in the flow of TLR4- PKC- $\varepsilon$ - TRAM- IFN- $\beta$ pathway (McGettrick et al. 2006).

\subsubsection{PKC- $\zeta$}

As a more atypical isoform, component of IL-1R and TNFR intracellular signaling pathways PKC$\zeta$ was reported more than 15 years ago (Hirai and Chida 2003; Duran et al. 2003). PKC- $\zeta$ was shown to be involved in TLR, IRAK, RhoA, and NF- $\kappa B$ activation (Yang et al. 2007; Huang et al. 2009). Using PKC- $\zeta$ specific inhibitors, ERK activation and TNF- $\alpha$ secretion was blocked upon Mycobacterium tuberculosis (MTB) stimulation (Yang et al. 2007). PKC- $\zeta$ was found associated with TLR2 but not TLR4. Thus, in THP-1 cells (a cell line from an acute monocytic leukemia) PKC- $\zeta$ does not associate with TLR2. IRAK phosphorylation is a molecular event in the flow of TLR signaling and if it is degraded is a negative control of the signaling pathway. Using a set of protein kinase inhibitors, it was suggested that IRAK is actually a PKC- $\zeta$ substrate. Several studies have highlighted a role for RhoA in TLR signaling (Chen et al. 2009; Shibolet et al. 2007; Manukyan et al. 2009; Lin et al. 2010). In monocytes it was found that the activation of p65 through TLR2 ligands needs RhoA and PKC- $\zeta$ activation. PKC- $\zeta$ transitorily links to RhoA that is activated and such, PKC $\zeta$ aids the observed effect of RhoA on gene transcription. Huang et al. have shown that
PKC- $\zeta$ is associated to RhoA in LPS-stimulated macrophages and by inhibiting RhoA or TRAF6, the PKC- $\zeta$ activation was blocked. Analogous experiments showed that inhibition of PKC- $\zeta$ blocked TAK1 phosphorylation (Huang et al. 2009). Thus actually PKC- $\zeta$ is a link in the flow of TLR2/4-RhoA/TRAF6- PKC - TAK1 p65 - cytokine induction.

Various forms of PKCs are involved in the large family of TLRs activation mediating important effector functions in innate immune cells.

\section{$3 \quad$ PKCs in T-Cell Receptor Signaling}

In contrast to innate immunity, adaptive immunity discriminates minute differences between aggressors. The immune system encounters during its life span a myriad of antigens and hence can specifically raise an immune response towards all the encountered pathogens and antigens. Adaptive immunity would develop a slow but long-lasting specific immune response. $\mathrm{T}$ cells and $\mathrm{B}$ cells receptors are designed to recognize all potential antigens.

The first stage of recognition in both cell types is the specific linkage with the specific domains in the antigen followed by activation of a single specific cell type. This recognition would trigger cells to proliferate (clonal expansion). Recognition of specific domains on the antigen is done by a specific TCR structurally different from that of BCR. Intracellular signaling triggered by the activation of TCR has both common and different pathways with $\mathrm{BCR}$ as further described (Acuto and Cantrell 2000).

\subsection{PKCs Families}

TCR as being the complex molecular structure delivering the antigen specific recognition is a heterodimer of either $\alpha \beta$ or $\gamma \delta$ polypeptides that contain variable regions, responsible for the binding to the complex of antigen peptide-major histocompatibility complex (MHC). In order to 
efficiently deliver signals upon activation these chains associate with signal transducing components, CD3 complex, process needed for both cell expression and function accomplishment. The CD3 complex which has 3 parts, $\zeta$ part being intimately involved in the intracellular signaling pathway would develop the activation pathway (Favero and Lafont 1998). TCR will recognize the antigen presented by the antigenpresenting cells (APCs) and this "immunological synapse" will lead to T-cell differentiation and activation; a multifactorial process including PKC signaling. After TCR-MHC complex formation, PKC localizes to the complex and generates the activation of nuclear transcription factors for further induction of immune effector genes (Isakov and Altman 2002). Activated genes will generate both soluble molecules, like cytokines, chemokines, growth factors and transient cell surface molecules to induce T-cell proliferation and differentiation (Smith-Garvin et al. 2009; Fooksman et al. 2010; Yokosuka and Saito 2010).

There are several PKC isoforms that are involved in the TCR intracellular signaling events.

\subsubsection{PKC $\theta$}

The most predominant isoform used by $\mathrm{T}$ cell activation is $\mathrm{PKC} \theta$, while in different $\mathrm{T}$ cell subsets other forms can be identified as well (Kong and Altman 2013). This PKC $\theta$ isoform is expressed in $\mathrm{T}$ cells within the haematopoietic cell population as shown in the early 90s (Baier et al. 1993). Further studies have shown that after activation, PKC $\theta$ translocates to the plasma membrane associating with the co-stimulatory molecule CD28 through its V3 domain (Kong et al. 2011; Yokosuka et al. 2008). In CD28deficient mice it was shown that PKC $\theta$ needs the presence of CD28 in activated T cells to develop a mature immunological synapse. PKC $\theta$ is regulated also by the intracellular redox state, and in 2013 the first published study has shown in naive $\mathrm{T}$ cells that the oxidized inactive PKC $\theta$ is recruited to the cell membrane and that this process of PKC- $\theta$ activation is redox dependent and needs de novo synthesis of glutathione (von Essen et al. 2013). Afterwards, the dependence of
PKC to the oxidative state was proven in muscular disorders as well (Dobrowolny et al. 2018).

In PKC $\theta$-knockout mice, PKC $\theta$ involvement in T-cell signaling was reported more than 15 years ago (Pfeifhofer et al. 2003) and studies that related its dis-functionality in autoimmune diseases followed (Anderson et al. 2006). In mouse experimental models of autoimmune encephalomyelitis it was shown that in PKC $\theta$ deficient mice type Th1 responses are deregulated. Th17 involvement in developing this experimental autoimmune encephalomyelitis needs PKC $\theta$ because it controls Th17 differentiation (SalekArdakani et al. 2005; Tan et al. 2006).

PKC $\theta$ controls signal transducer and activator of transcription 3 (STAT3) after Th17 activation by association of activator protein 1 and NF-kB transcription factors to the STAT3 promoter (Kwon et al. 2012). PKC $\theta$ was reported to suppress Stat4, Tbet (T-box transcription factor) and IFN $\gamma$ upon Th17 activation (Wachowicz et al. 2014).

In immune memory control PKC $\theta$ is also involved. Thus in the antiviral responses performed by $\mathrm{CD} 8+\mathrm{T}$-cell, $\mathrm{PKC} \theta$ is needed for the antigen immune recall upon re-infection with lymphocytic choriomeningitis virus and influenza virus (Marsland and Kopf 2008) and for developing memory T-cell per se (Teixeiro et al. 2009).

In regulatory $\mathrm{T}$ cells (Treg) PKC $\theta$ is localized apart from the immunological synapse, process that leads to a negative regulation of Tregs (Gupta et al. 2008; Zanin-Zhorov et al. 2010). The effect of negative regulation performed by $\mathrm{PKC} \theta$ is an inhibited differentiation of Tregs via the AKT/ Foxo1/3a pathway (Ma et al. 2012).

$\mathrm{PKC} \theta$ has an important role in T-cell immune response regulation and an outline of the main steps in TCR signaling involving PKC $\theta$ is depicted in Fig. 5.2.

\subsubsection{PKC- $\alpha$}

DAG messengers are involved in TCR signaling, but more recently it was demonstrated that it can regulate the duration and amplitude of Ras/ERK signals. Thus, it was shown that PKC $\alpha$ is transiently translocating, process mediated by DAG generation in the contact area of the immune 
Fig. 5.2 TCR signaling pathway involving PKCO. Upon TCR stimulation, activation of co-stimulatory CD8 induces the translocation of PKC $\theta$; activation induces further the aggregation and phosphorylation of caspase-recruitment domain containing membrane-associated guanylate kinase protein-1 (CARMA1). Aggregated CARMA1 will complex with B cell lymphoma 10 (Bcl-10) and mucosal-associated lymphoid-tissue lymphoma-translocation gene 1 (Malt1). Malt1 in the CBM complex will induce the degradation of the IKK regulatory component, IkB, via activation of TRAF6 and transforming TAK1, the process leading to the activation and nuclear translocation of NF-kB

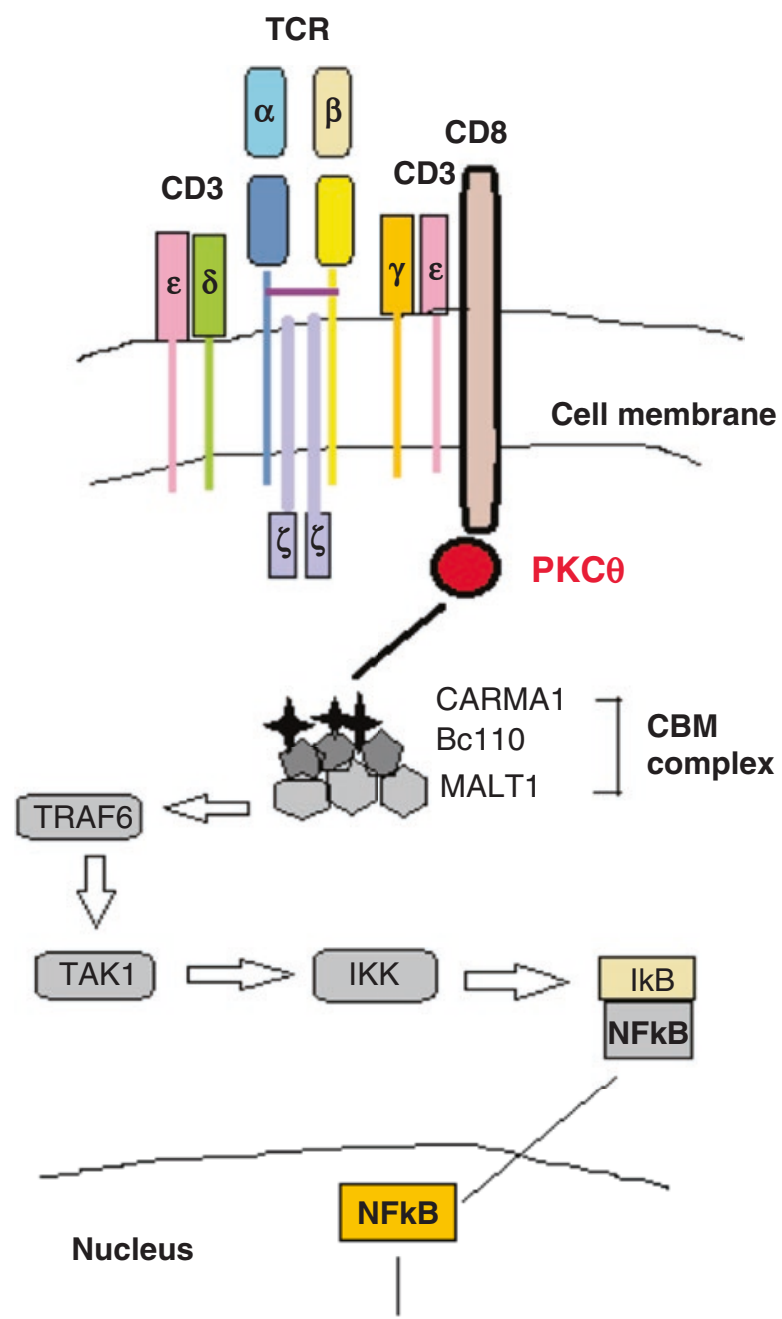

Cytokines synapse. It was demonstrated that Diacylglycerol kinase $(\mathrm{DGK}) \zeta$ can negatively regulate $\mathrm{PKC} \alpha$ translocation kinetics, while PKC $\alpha$ is selflimiting in the immune synapse. These two pillars DGK $\zeta$ and PKC $\alpha$ would regulate the amplitude and duration of Ras/ERK activation after antigen recognition. In animal models characterized by deficient DGK $\zeta$ it was demonstrated that increased DAG signaling induces enhanced PKC $\alpha$-dependent L-selectin shedding. Thus Gharbi et al. depicted that the early activation of DAG-PKC $\alpha$ axis induces TCR biological responses (Gharbi et al. 2013).

Markers that can detect pathologies associated to $T$ cells were studied by immunohistochemistry approaches, PKC isoforms included. Thus GADS (GRB2-related adaptor protein 2), DOK2 (Docking protein), SKAP55 (src family associated phosphoprotein), ITK (Interleukin-2 inducible T-cell kinase) markers were associated with lymphoid and myeloid precursor neoplasms. PKC $\alpha$ was found defective in angioimmunoblastic T-cell lymphoma and aberrantly expressed in classical Hodgkin lymphoma, Burkitt lymphoma and plasma cell myeloma. Probably future studies will develop PKC $\alpha$ as a new therapy target (Agostinelli et al. 2014).

Further work on PKC $\alpha$ involvement in TCR signaling has shown that $\mathrm{Ca}^{2+}$ elevation is separate from the control of I $\mathrm{KB} \alpha$ degradation, 
and that the regulatory action via $\mathrm{Ca}^{2+}$ is dependent on PKC $\alpha$-mediated phosphorylation of p65. Therefore this recent study established a check point controller of $\mathrm{Ca}^{2+}$ signaling event as being PKC $\alpha$ (Liu et al. 2016).

A study published in 2019 by Merida et al. has shown that in $\mathrm{T}$ lymphocytes, the interaction between DGK $\zeta$ and Sorting Nexin 27 (SNX27) controls PKC $\alpha$ activation. When silencing SNX27 in T lymphocytes, PKC $\alpha$ activation is enhanced, finding that provides molecular basis for the $\mathrm{DGK} \zeta-\mathrm{PKC} \alpha$ deregulations in immune synapse impairment (Mérida et al. 2019).

\subsubsection{PKC $\delta$}

PKCס isoform was first identified in a mouse model as a PKC family member that is required for the control of lytic granule exocytosis by CD8+ T cells. Thus PKC $\delta$ isoform, although it was shown to regulate this process, was found unessential for activation and cytokine production (Ma et al. 2007). Other studies followed, showing PKC $\delta$ involvement in TCR activation. As shown in the previous section, TCR and costimulatory receptors activation have CARMA1 (caspase recruitment domain-containing membrane-associated guanylate kinase 1) as a seminal protein. CARMA1 will recruit B-cell CLL/lymphoma 10 (Bcl10), mucosaassociated lymphoid tissue lymphoma translocation gene 1 (MALT1), and TRAF6 assembling a specific signalosome that would trigger $\mathrm{NF}-\kappa \mathrm{B}$ activation. In a cellular model with Jurkat T cells, PKC $\delta$ was shown to associate with CARMA1 and the over-expression of PKC $\delta$ inhibited NF- $\kappa \mathrm{B}$ activation through CARMA1. Alternatively, when knocking down PKCס, NF- $\kappa \mathrm{B}$ activation and IL-2 secretion was noticed. All these results indicated PKC $\delta$ as a negative regulator in $\mathrm{T}$ cell activation (Liu et al. 2012).

In 2019, it was shown that PKC $\delta$ regulates TCR-controlled multivesicular bodies polarization toward the immune synapse and exosome secretion. Moreover at the immune synapse the reorganization of $\mathrm{F}$-actin is inhibited in $\mathrm{T}$ lymphocytes were $\mathrm{PKC} \delta$ is obstructed. Therefore, PKC $\delta$ is recently proposed as actin reorganization regulator in the immune synapse (Herranz et al. 2019).

In TCR signaling there are PKCs that up-regulate activation of adaptive immune functions, but also kinases that are negative regulators of this cell type.

\section{$4 \quad$ B-Cell Receptor Signaling}

Mature B lymphocytes are a critical component of the adaptive immunity participating to systemic defense by generating highly specific antibodies, regulatory cytokines, chemokines and presenting antigen to $\mathrm{T}$ cells to generate an immune response against tumors and pathogens (Harwood and Batista 2008).

B cell activation is initiated upon specific antigen capturing by BCR, this event will trigger various intricate intracellular pathways mediated by Src-family kinases as well as Syk and Bruton's tyrosine kinases $(\mathrm{Btk}) / \mathrm{Tec}$ that cooperate to uptake the antigen-receptor complex. All this organized assemble of kinases and adaptor proteins form the so called signalosome that activates multiple signalling pathways (Packard and Cambier 2013; Lim et al. 2015). Besides antigen capturing, growth and proliferation of B cells are closely regulated through $\mathrm{BCR}$ signaling and other membrane receptors that would be activated by different cytokines (Jellusova and Rickert 2016; Taher et al. 2017).

BCR is a heterodimeric transmembrane protein composed of heavy-chain and light chain immunoglobulins, CD79A/Ig $\alpha$ and CD79B/Ig $\beta$ and located on B cells outer surface (Stephenson and Singh 2017). The engulfed antigen via BCR is processed and presented on B cell surface as specific peptides associated with MHC-II molecules; this process results in the assignation of specific $\mathrm{T}$ helper lymphocytes that would provide a second signal for complete $\mathrm{B}$ cell activation. Further, activated B cells can differentiate to antibody-secreting plasma cells or enter into germinal centers (GCs) where cells are subjected to BCR affinity maturation and antibody class switch recombination (De Silva and Klein 2015). Subsequently B cells would 
leave the GC and differentiate into either highaffinity antibody secreting long-term plasma cells or dormant memory B cells that can reactivate as plasma cells upon re-encountering with the same antigen (Tsui et al. 2018; Kurosaki et al. 2010).

\subsection{PKCs Role in BCR Signaling Events}

Antigen binding to the BCR and further B cell activation rely on PKC that is translocated from cytosol to the plasma membrane where spatially there are regions comprising the tetraspanin protein CD53 to sustain BCR-dependent PKC stimulation (Zuidscherwoude et al. 2017).

The PKC is a large family of Ser/Thr kinases with pleiotropic expression and controlling many cellular functions like development, differentiation, activation, lymphocytes survival and immune responses development (Tan and Parker 2003; Cooke et al. 2017). From the previously section, the described isoforms of $\operatorname{PKC} \beta, \lambda$, and $\zeta$ variants prevail in B cells with PKC $\beta$ the most ubiquitously expressed and most important isoform in BCR signaling (Isakov 2018).

The role of $\mathrm{PKC} \beta$ in regulating B-cell function was initially revealed through PKC $\beta$ gene knockout mice that exhibited decreased B-cell activation, no proliferation upon BCR activation and altered T-cell-independent immune responses (Leitges et al. 1996).

In establishing the signalosome, the isoform $\beta$ of PKCs mediates phosphorylation of CARMA1 protein leading to a multipart complex comprising CARMA1, Bcl10 and MALT1 linked to membrane lipid rafts (Shinohara et al. 2007). A general outline of the intracellular signaling events triggered by BCR activation regulated by $\mathrm{PKC} \beta$ is presented in Fig. 5.3. However, alterations in $\mathrm{B}$ cell responses can lead to pathological conditions such as autoimmune diseases when high-affinity autoreactive B lymphocytes develop and produce autoantibodies leading to tissue damaging.

Outlining biomarkers that designate an abnormal B cell response can assist in elucidating dis- ease mechanisms and provide new therapeutic avenues for precision medicine (Taher et al. 2017).

Another B cells subclass essential in immune homeostasis maintenance is represented by regulatory B lymphocytes (Bregs) that modulate immune responses mostly via anti-inflammatory cytokines (e.g. IL-10) enabling Tregs commencement, and thus hindering anti-tumor responses. Aberrations in Breg numbers and function have been observed in immune-related pathologies, including cancer. However, despite a pivotal role for Bregs in upholding inflammation and carcinogenesis, the phenotypic diversity of the Bregs remains unclear (Mauri and Menon 2017; Sarvaria et al. 2017). The PKC $\beta$ is actively involved in NF-kB signaling cascade upon BCR engagement that initiate an influx of $\mathrm{Ca}^{2+}$ into the cytoplasm (Saijo et al. 2002). Secondary mediators such as DAG are generated as part of the BCR activation cascade to initiate $\mathrm{Ca}^{2+}$ influx and PKCs signaling events, leading to activation of several transcription factors (Myc, NF-kB, activator protein 1 etc.) essential for B-cell life program (Packard and Cambier 2013).

The mandatory role of PKC isoforms and their involvement in NF- $\mathrm{KB}$ pathway modulation in lymphocytes is well known (Guo et al. 2004). The membrane localization of $\mathrm{PKC} \beta$ is favorable for IкB kinase (IKK) complex activation that is tightly regulated by $\mathrm{Ca}^{2+}$ levels (Guo et al. 2004; Berry et al. 2018). The enzyme complex IKK is located in the upstream of the NF- $\kappa \mathrm{B}$ signaling cascade playing an essential role for B cells development and function (Kaisho et al. 2001). PKC $\beta$ has a significant role in IKK cascade as IKK becomes activated upon phosphorylation of the adaptor protein CARMA1 by PKC $\beta$; this will fit together IKK and TAK1 allowing TAK1 to phosphorylate and activate IKK. As a consequence, IkB is further phosphorylated by IKK leading to NF-kB activation, highlighting the role of PKC $\beta$ in BCR-triggered NF-kB pathway (Shinohara et al. 2005; Thome et al. 2010).

The central mechanism that regulates intracellular $\mathrm{Ca}^{2+}$ levels in lymphocytes is represented by store-operated calcium entry (SOCE) through calcium release-activated calcium (CRAC) comprising Stromal Interaction Molecule 1 and 2 
Fig. 5.3 BCR signaling pathway involving PKC $\beta$. B cells are activated after antigen binding to BCR that needs for intracellular signaling CD79 molecules. In B cells pathways involving PKC $\beta$ are triggered. One common intracellular pathway with TCR signaling is the CBM complex activating finally the nuclear NFkB. Secondary messengers (DAG) are generated upon PLC $\gamma 1$ activation that due to generated calcium $\left(\mathrm{Ca}^{2+}\right)$ would activate PKC $\beta$.

3-phosphoinositide dependent protein kinase-1 (PDK1) activated through phosphoinositide 3-kinase (PI3K) would activate $\mathrm{PKC} \beta$. The signaling pathways lead to the activation of nuclear transcription factors: NFkB, activator protein 1 (AP1) and nuclear factor of activated $\mathrm{T}$ cells (NFAT) that will induce cytokines' synthesis

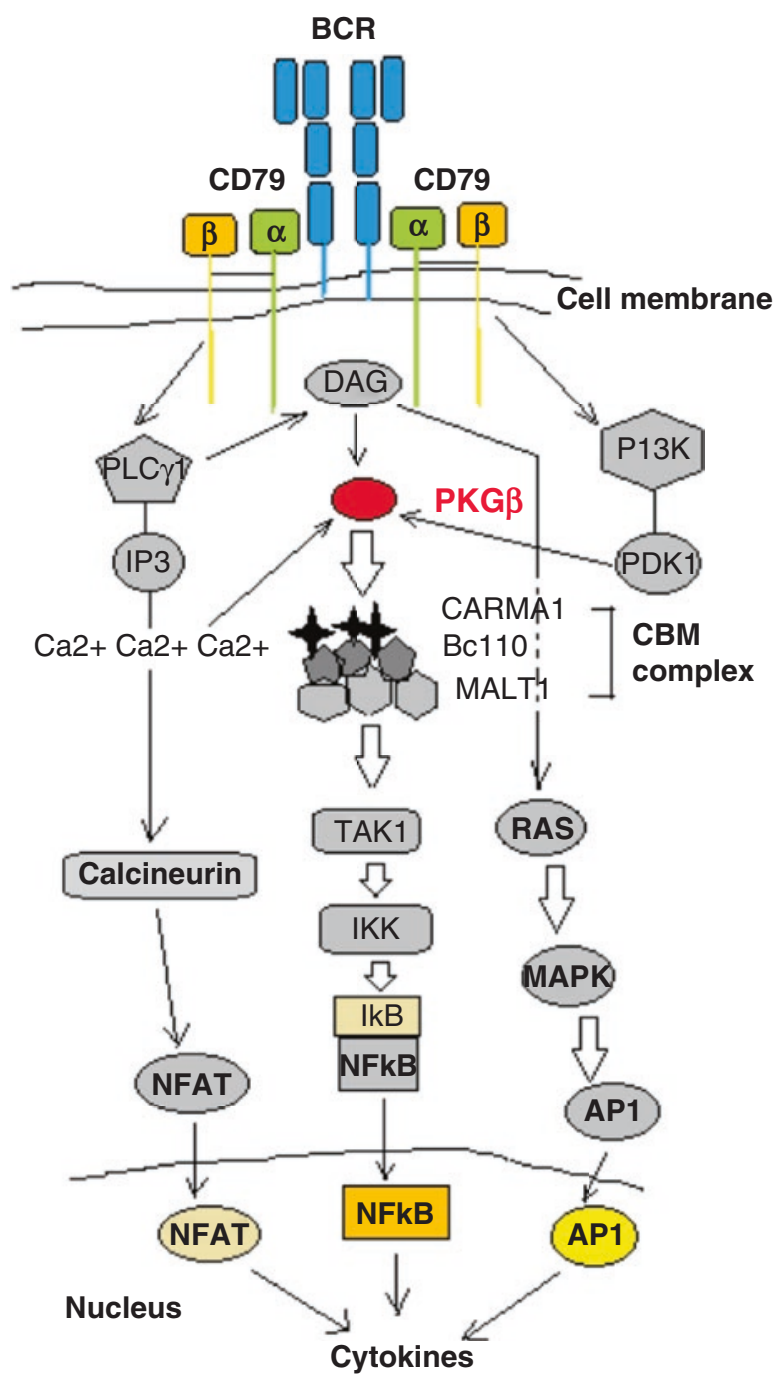

both NF- $\kappa \mathrm{B}$ and NFAT factors. An intermediary antigen affinity binding to BCR causes possibly $\mathrm{Ca}^{2+}$ fluctuations that preferentially activate NF-кB. Faint interactions in antigen-BCR complex will generate a transitory raise in cytosolic $\mathrm{Ca}^{2+}$ leading to the selective activation of NF- $\mathrm{\kappa B}$ dependent gene expression. Thus $\mathrm{Ca}^{2+}$ levels dictated by bonding strength in antigen-receptor complex are able to regulate important checkpoints in canonical NF- $\kappa \mathrm{B}$ signaling in both $\mathrm{T}$ and $\mathrm{B}$ lymphocytes. More accurately, in resting lymphocytes, homo- and heterodimers of NF- $\mathrm{\kappa B}$ p50, p65, and c-Rel proteins are sequestered in the cytosol by I $\mathrm{I} B$ proteins including I $\mathrm{B} \alpha$. BCR engagement activates a series of PTKs, $\beta$ isoOrai-mediated $\mathrm{Ca}^{2+}$ entrance and activation of antigen interaction with BCR will cause STIM/

(Feske 2007). STIM and Orai channels discovery, almost a decade ago, has advanced knowlge regarding $\mathrm{Ca}^{2+}$ multiple actions such receptor that would trigger distinct patterns of gene expression responsible for a distinct transcriptionally fate in lymphocytes' life. Interestingly, a clear connection between strength of antigen binding to $\mathrm{BCR}$, pro-inflammatory transcription factors NF- $\mathrm{KB}$ and NFAT and $\mathrm{Ca}^{2+}$ levels effects was reported. Thus, a high affinity 
forms in case of BCR, that subsequently activate PLC $\gamma$ isoforms, cleaving PI(4,5)P2 to IP3 and DAG. Further, IP3 binds to IP3 receptors channels from endoplasmic reticulum (ER) allowing release of $\mathrm{Ca}^{2+}$ in cytosol. The resulting collapse of $\mathrm{Ca}^{2+}$ level in ER induce STIM1 proteins oligomerization and stimulation of plasma membrane Orai1 channels enabling extracellular $\mathrm{Ca}^{2+}$ admission and a significant elevation in cytoplasmic $\mathrm{Ca}^{2+}$ level. STIM1 plays a dominant role in BCR-induced Orai1 activation while STIM2 regulates cytosolic $\mathrm{Ca}^{2+}$ levels in quiescent conditions (Roos et al. 2005; Liou et al. 2005; Berry et al. 2018). Additional roles for STIM/Orai in B cell life were revealed in Bregs where expression of immunosuppressive cytokines IL-10 and TGF- $\beta$ are deficient in the absence of STIM/Orai mediated $\mathrm{Ca}^{2+}$ channels (Berry et al. 2018).

Recent data designate a critical role of PKC $\beta$ in antigen polarization which is supposed to enable the effective antigen processed peptides linking to MHC-II molecules. Mice with PKC $\beta$ deficient $\mathrm{B}$ cells would exhibit impaired antigen polarization and presentation that could hinder GC development, thus highlighting the significant role of PKC $\beta$ in B cells fate determination and metabolic program (Tsui et al. 2018).

In the last years there were several studies revealing that $\mathrm{PKC}$ could intercede as a possible target in B cell diseases taking into account that deregulation in BCR signaling represents one of the mark for activated B-cell diffuse large B-cell lymphoma (ABC-DLBCL); a number of BCR targeted therapies are current in progress, including kinase inhibitors against PKC (Stephenson and Singh 2017; Kuppers 2005).

$\mathrm{PKC} \beta \mathrm{II}$ is overexpressed in chronic lymphocytic leukemia (CLL) where it's associated with poor prognosis and survival as well as with anticancer drug resistance development (Kabir et al. 2013; Kazi et al. 2013). PKC $\beta I I$ is viewed as a potential therapeutic target for CLL treatment but inhibition of PKC $\beta$ II with specific inhibitors (e.g., LY379196). This inhibitor had a minor effect on the cellular viability and failed to induce a decrease of mRNA levels for PKC $\beta$ II in CLL cells. Certain growth factors like VEGF seem to sustain PKC $\beta$ II activity. In a milieu deprived of VEGF there is a clear inhibition of PKC $\beta$ II by LY379196 (Abrams et al. 2010). The role of PKCs in CLL cell survival is to inhibit pro-apoptotic signals and stimulate pro-survival ones (PKC $\beta$ II) and activate anti-apoptotic effectors like NOTCH2 (PKC8) (Hubmann et al. 2010; Kang 2014). Furthermore, PKC $\delta$ regulates peripheral B-cell development and immune homeostasis (Salzer et al. 2016) and mediates mitochondrial-dependent apoptosis in an epigenetic manner like phosphorylating histones at specific residues such as $\mathrm{H} 3 \mathrm{~S} 10$ or $\mathrm{H} 3 \mathrm{~T} 45$ known to be linked to apoptosis (Hurd et al. 2009; Park and Kim 2012).

PKC $\delta$ is recognized to be involved in autoimmunity as recently, autosomal recessive mutations in gene encoding PKC $\delta$ have been identified in patients with systemic lupus erythematosus. Moreover Prkcd-/- knockout mice models revealed a distinctive role of $\mathrm{PKC} \delta$ in controlling B-cell tolerance as immune complex-mediated glomerulonephritis, lymphadenopathy, splenomegaly, and multi-organ infiltrations of B cells were observed in this animal model (Miyamoto et al. 2002). Therefore the mechanisms of B-cell tolerance could be elucidated studying PKC $\delta$ related deficiencies (Salzer et al. 2016) as well as its immune therapy targeting (Lim et al. 2015).

Nevertheless, after almost three decades of cancer clinical trials with targeting PKC inhibitors, the results are still controversial for patient outcome. Increasing evidence from cancer genomic and proteomic outline provide a novel research line where $\mathrm{PKCs}$ isoenzymes largely act as tumor suppressors and therefore their activity should be restored instead of inhibited in antitumor approaches (Newton 2018). However the clear immunologic role of PKC in lymphocytes biology is still to be portrayed and progresses in this area are still to come (Harton 2019). 


\section{Conclusion}

PKCs in the immune system have become a check -point for seminal functions and control of intracellular signaling events. Nevertheless, after almost three decades of fundamental studies and cancer clinical trials targeting PKC with inhibitors, there is still information lacking. For example in the clinical trials results there are still controversies and sometimes even the clinical outcome of the patient subjected to this therapy worsed. Increasing evidence from cancer genomic and proteomic outline provide a novel approaches namely PKCs isoenzyme largely act as tumor suppressors and therefore their activity should be restored instead of inhibited in antitumor approaches (Newton 2018). However the clear immunologic role of PKC in lymphocytes biology is still to be portrayed. Apart from its potential role in antigen presentation and TCR/BCR triggered events immune cell activation/differentiation and transcriptomic pattern related events, still little is known about the contribution of PKC to cell's immunobiology.

\section{Acknowledgements}

This research was funded by UEFISCDI Projects PN-IIIP1-1.2-PCCDI-2017-0341 (acronym PATHDERM), PN-III-P1-1.2-PCCDI-2017-0782 (acronym REGMED) and PN.19.29.01.01/2019.

\section{References}

Abrams ST, Brown BR, Zuzel M, Slupsky JR, Abrams ST, Brown BRB, Zuzel M, Slupsky JR. Vascular endothelial growth factor stimulates protein kinase $\mathrm{C}$ $\beta$ II expression in chronic lymphocytic leukemia cells. Blood. 2010;115(22):4447-54.

Acuto O, Cantrell D. T cell activation and the cytoskeleton. Annu Rev Immunol. 2000;18:165-84.

Agostinelli C, Rizvi H, Paterson J, Shende V, Akarca AU, Agostini E, Fuligni F, Righi S, Spagnolo S, Piccaluga PP, Clark EA, Pileri SA, Marafioti T. Intracellular TCR-signaling pathway: novel markers for lymphoma diagnosis and potential therapeutic targets. Am J Surg Pathol. 2014;38(10):1349-59.
Akira S, Takeda K. Toll-like receptor signaling. Nat Rev Immunol. 2004;4:499-511.

Aksoy E, Goldman M, Willems F. Protein kinase C epsilon: a new target to control inflammation and immune mediated disorders. Int J Biochem Cell Biol. 2004;36(2):183-8.

Alcain J, Podaza E, Gori MS, Salamone G, Vermeulen M. Modulation of dendritic cell apoptosis and CD8+ cytotoxicity by histamine: role of protein kinase C. Mediat Inflamm. 2017;6:1-12.

Ali AS, Ali S, El-Rayes BF, Philip PA, Sarkar FH. Exploitation of protein kinase C: a useful target for cancer therapy. Cancer Treat Rev. 2009;35(1):1-8.

Anderson K, Fitzgerald M, Dupont M, Wang T, Paz N, Dorsch M, Healy A, Xu Y, Ocain T, Schopf L, Jaffee B, Picarella D. Mice deficient in PKC h demonstrate impaired in vivo $\mathrm{T}$ cell activation and protection from $\mathrm{T}$ cell-mediated inflammatory diseases. Autoimmunity. 2006;39:469-78.

Asehnoune K, Strassheim D, Mitra S, Yeol Kim J, Abraham E. Involvement of PKCalpha/beta in TLR4 and TLR2 dependent activation of NF-kappaB. Cell Signal. 2005;17(3):385-94.

Baeuerle PA, Henkel T. Function and activation of NF-kappaB in the immune system. Annu Rev Immunol. 1994;12:141-79.

Baier G, Telford D, Giampa L, Coggeshall KM, BaierBitterlich G, Isakov N, Altman A. Molecular cloning and characterization of $\mathrm{PKC} h$, a novel member of the protein kinase $\mathrm{C}$ (PKC) gene family expressed predominantly in hematopoietic cells. J Biol Chem. 1993;268:4997-5004.

Berry CT, May MJ, Freedman BD. STIM- and Oraimediated calcium entry controls NF- $\kappa \mathrm{B}$ activity and function in lymphocytes. Cell Calcium. 2018;74:131-43.

Bhatt KH, Pandey RK, Dahiya Y, Sodhi A. Protein kinase Cdelta and protein tyrosine kinase regulate peptidoglycan-induced nuclear factor-kappaB activation and inducible nitric oxide synthase expression in mouse peritoneal macrophages in vitro. Mol Immunol. 2010;47(4):861-70.

Bynagari-Settipalli YS, Chari R, Kilpatrick L, Kunapuli SP. Protein kinase $\mathrm{C}$ - possible therapeutic target to treat cardiovascular diseases. Cardiovasc Hematol Disord Drug Targets. 2010;10(4):292-308.

Castrillo A, Pennington DJ, Otto F, Parker PJ, Owen MJ, Bosca L. Protein kinase Cepsilon is required for macrophage activation and defense against bacterial infection. J Exp Med. 2001;194(9):1231-42.

Catley MC, Cambridge LM, Nasuhara Y, Ito K, Chivers JE, Beaton A, Holden NS, Bergmann MW, Barnes PJ, Newton R. Inhibitors of protein kinase C (PKC) prevent activated transcription: role of events downstream of NF-kappaB DNA binding. J Biol Chem. 2004;279(18):18457-66.

Cejas PJ, Carlson LM, Zhang J, Padmanabhan S, Kolonias D, Lindner I, Haley S, Boise LH, Lee KP. Protein kinase $\mathrm{C}$ betaII plays an essential role in dendritic cell 
differentiation and autoregulates its own expression. J Biol Chem. 2005;280(31):28412-23.

Chano F, Descoteaux A. Modulation of lipopolysaccharide-induced NF-IL6 activation by protein kinase $\mathrm{C}$-alpha in a mouse macrophage cell line. Eur J Immunol. 2002;32(10):2897-904.

Chen Q, Gupta S, Pernis AB. Regulation of TLR4mediated signaling by IBP/Def6, a novel activator of Rho GTPases. J Leukoc Biol. 2009;85(3):539-43.

Churchill E, Budas G, Vallentin A, Koyanagi T, MochlyRosen D. PKC isozymes in chronic cardiac disease: possible therapeutic targets? Annu Rev Pharmacol Toxicol. 2008;48:569-99.

Comalada M, Xaus J, Valledor AF, Lopez-Lopez C, Pennington DJ, Celada A. PKC epsilon is involved in JNK activation that mediates LPS-induced TNFalpha, which induces apoptosis in macrophages. Am J Physiol Cell Physiol. 2003;285(5):C1235-45.

Cooke M, Magimaidas A, Casado-Medrano V, Kazanietz MG. Protein kinase $\mathrm{C}$ in Cancer: the top five unanswered questions. Mol Carcinog. 2017;56:1531-42.

De Silva NS, Klein U. Dynamics of B cells in germinal centres. Nat Rev Immunol. 2015;15:137-48.

Dobrowolny G, Martini M, Scicchitano BM, Romanello V, Boncompagni S, Nicoletti C, Pietrangelo L, De Panfilis S, Catizone A, Bouchè M, Sandri M, Rudolf R, Protasi F, Musarò A. Muscle expression of SOD1 ${ }^{\mathrm{G} 93 \mathrm{~A}}$ triggers the dismantlement of neuromuscular junction via PKC-theta. Antioxid Redox Signal. 2018;28(12):1105-19.

Duran A, Diaz-Meco MT, Moscat J. Essential role of RelA Ser311 phosphorylation by zetaPKC in NF-kappaB transcriptional activation. EMBO J. 2003;22(15):3910-8.

Durgan J, Cameron AJ, Saurin AT, Hanrahan S, Totty N, Messing RO, Parker PJ. The identification and characterization of novel PKCepsilon phosphorylation sites provide evidence for functional cross-talk within the PKC superfamily. Biochem J. 2008;411(2):319-31.

Faisal A, Saurin A, Gregory B, Foxwell B, Parker PJ. The scaffold MyD88 acts to couple protein kinase Cepsilon to Toll-like receptors. J Biol Chem. 2008;283(27):18591-600.

Favero J, Lafont V. Effector pathways regulating T cell activation. Biochem Pharmacol. 1998;56:1539-47.

Feske S. Calcium signalling in lymphocyte activation and disease. Nat Rev Immunol. 2007;7(9):690-702.

Foeyand AD, Brennan FM. Conventional protein kinase $\mathrm{C}$ and atypical protein kinase Czeta differentially regulate macrophage production of tumour necrosis factor-alpha and interleukin-10. Immunology. 2004;112(1):44-53.

Fooksman DR, Vardhana S, Vasiliver-Shamis G, Liese J, Blair DA, Waite J, Sacristán C, Victora GD, ZaninZhorov A, Dustin ML. Functional anatomy of T cell activation and synapse formation. Annu Rev Immunol. 2010;28:79-105.

Fronhofer V, Lennartz MR, Loegering DJ. Role of PKC isoforms in the $\mathrm{Fc}($ gamma)R-mediated inhibition of
LPS-stimulated IL-12 secretion by macrophages. J Leukoc Biol. 2006;79(2):408-15.

Gay NJ, Gangloff M. Structure and function of Toll receptors and their ligands. Annu Rev Biochem. 2007;76:141-5.

Gharbi SI, Avila-Flores A, Soutar D, Orive A, Koretzky GA, Albar JP, Mérida I. Transient PKC $\alpha$ shuttling to the immunological synapse is governed by DGK $\zeta$ and regulates L-selectin shedding. J Cell Sci. 2013;126(Pt 10):2176-86.

Gonelli A, Mischiati C, Guerrini R, Voltan R, Salvadori $\mathrm{S}$, Zauli G. Perspectives of protein kinase C (PKC) inhibitors as anti-cancer agents. Mini-Rev Med Chem. 2009;9(4):498-509.

Guo B, Su TT, Rawlings DJ. Protein kinase C family functions in B-cell activation. Curr Opin Immunol. 2004;16(3):367-73.

Gupta S, Manicassamy S, Vasu C, Kumar A, Shang W, Sun Z. Differential requirement of PKC-h in the development and function of natural regulatory T cells. Mol Immunol. 2008;46:213-24.

Harton JA. Class II MHC cytoplasmic domain-mediated signaling in B cells: a tail of two signals. Hum Immunol. 2019;80(1):32-6.

Harwood NE, Batista FD. New insights into the early molecular events underlying B cell activation. Immunity. 2008;28:609-19.

Herranz G, Aguilera P, Dávila S, Sánchez A, Stancu B, Gómez J, Fernández-Moreno D, de Martín R, Quintanilla M, Fernández T, Rodríguez-Silvestre P, Márquez-Expósito L, Bello-Gamboa A, Fraile-Ramos A, Calvo V, Izquierdo M. Protein kinase $\mathrm{C} \delta$ regulates the depletion of actin at the immunological synapse required for polarized exosome secretion by $\mathrm{T}$ cells. Front Immunol. 2019;10:851.

Hirai T, Chida K. Protein kinase Czeta (PKCzeta): activation mechanisms and cellular functions. J Biochem. 2003;133(1):1-7.

Holm A, Tejle K, Gunnarsson T, Magnusson KE, Descoteaux A, Rasmusson B. Role of protein kinase C alpha for uptake of unopsonized prey and phagosomal maturation in macrophages. Biochem Biophys Res Commun. 2003;302(4):653-8.

Huang X, Chen LY, Doerner Pan AM, Smith L, Huang S, Papadimos TJ, Pan ZK. An atypical protein kinase C (PKC zeta) plays a critical role in lipopolysaccharideactivated NF-kappa B in human peripheral blood monocytes and macrophages. J Immunol. 2009;182(9):5810-5.

Hubmann R, Düchler M, Schnabl S, Hilgarth M, Demirtas D, Mitteregger D, Hölbl A, Vanura K, Le T, Look T, Schwarzmeier JD, Valent P, Jäger U, Shehata M. NOTCH2 links protein kinase $\mathrm{C}$ delta to the expression of CD23 in chronic lymphocytic leukaemia (CLL) cells: research paper. Br J Haematol. 2010;148(6):868-78.

Hurd PJ, Bannister AJ, Halls K, Dawson MA, Vermeulen M, Olsen JV, Ismail H, Somers J, Mann M, OwenHughes T, Gout I, Kouzarides T. Phosphorylation of 
histone H3 Thr-45 is linked to apoptosis. J Biol Chem. 2009;284:6575-83.

Ikewaki N, Fujii N, Onaka T, Ikewaki S, Inoko H. Immunological actions of Sophy beta-glucan (beta1,3-1,6 glucan), currently available commercially as a health food supplement. Microbiol Immunol. 2007;51(9):861-73.

Isakov N. Protein kinase C (PKC) isoforms in cancer, tumor promotion and tumor suppression. Semin Cancer Biol. 2018;48:36-52.

Isakov N, Altman A. Protein kinase $\mathrm{C} \theta$ in T cell activation. Annu Rev Immunol. 2002;20:761-94.

Janeway CA Jr, Medzhitov R. Innate immune recognition. Annu Rev Immunol. 2002;20:197-216.

Jellusova J, Rickert RC. The PI3K pathway in B cell metabolism. Crit Rev Biochem Mol Biol. 2016;51(5):359-78.

Joffre OP, Segura E, Savina A, Amigorena S. Cross presentation by dendritic cells. Nat Rev Immunol. 2012;12(8):557-69.

Johnson J, Albarani V, Nguyen M, Goldman M, Willems F, Aksoy E. Protein kinase Calpha is involved in interferon regulatory factor 3 activation and type I interferon-beta synthesis. J Biol Chem. 2007;282(20):15022-32.

Kabir NN, Rönnstrand L, Kazi JU. Protein kinase C expression is deregulated in chronic lymphocytic leukemia. Leuk Lymphoma. 2013;54(10):2288-90.

Kaisho T, Takeda K, Tsujimura T, Kawai T, Nomura F, Terada N, Akira S. IкB kinase $\alpha$ is essential for mature B cell development and function. J Exp Med. 2001;193:417-26.

Kang J-H. Protein kinase C (PKC) isozymes and cancer. New J Sci Rev. 2014;2014:36, Article ID 231418.

Kawai T, Akira S. The role of pattern-recognition receptors in innate immunity: update on Toll-like receptors. Nat Immunol. 2010;11(5):373-84.

Kazi JU, Kabir NN, Rönnstrand L. Protein kinase C, (PKC) as a drug target in chronic lymphocytic leukemia. Med Oncol. 2013;30(4):757.

Kilpatrick LE, Standage SW, Li H, Raj NR, Korchak HM, Wolfson MR, Deutschman CS. Protection against sepsis-induced lung injury by selective inhibition of protein kinase C- $\delta(\delta-P K C)$. J Leukoc Biol. 2011;89(1):3-10.

Kong K-F, Altman A. In and out of the bull's eye: protein kinase $\mathrm{Cs}$ in the immunological synapse. Trends Immunol. 2013;34:234-42.

Kong KF, Yokosuka T, Canonigo-Balancio AJ, Isakov N, Saito T, Altman A. A motif in the V3 domain of the kinase PKC- $\theta$ determines its localization in the immunological synapse and functions in $\mathrm{T}$ cells via association with CD28. Nat Immunol. 2011;12:1105-12.

Koyanagi T, Noguchi K, Ootani A, Inagaki K, Robbins RC, Mochly-Rosen D. Pharmacological inhibition of epsilon PKC suppresses chronic inflammation in murine cardiac transplantation model. J Mol Cell Cardiol. 2007;43(4):517-22.
Kubo-Murai M, Hazeki K, Sukenobuetal N. Protein kinase $\mathrm{C}$ delta binds TIRAP/Mal to participate in TLR signaling. Mol Immunol. 2007;44(9):2257-64.

Kuppers R. Mechanisms of B-cell lymphoma pathogenesis. Nat Rev Cancer. 2005;5:251-62.

Kurosaki T, Shinohara H, Baba Y. B cell signaling and fate decision. Annu Rev Immunol. 2010;28:21-55.

Kwon MJ, Ma J, Ding Y, Wang R, Sun Z. Protein kinase C- $\theta$ promotes Th17 differentiation via upregulation of Stat3. J Immunol. 2012;188:5887-97.

Langlet C, Springael C, Johnson J, Thomas S, Flamand V, Leitges M, Goldman M, Aksoy E, Willems F. PKCalpha controls MYD88-dependent TLR/IL-1R signaling and cytokine production in mouse and human dendritic cells. Eur J Immunol. 2010;40(2):505-15.

Leitges M, Schmedt C, Guinamard R, Davoust J, Schaal S, Stabel S, Tarakhovsky A. Immunodeficiency in protein kinase C $\beta$-deficient mice. Science. 1996;273:788-91.

Li X, Cullere X, Nishi H, Saggu G, Durand E, Mansour MK, Tam JM, Song XY, Lin X, Vyas JM, Mayadas T. PKC- $\delta$ activation in neutrophils promotes fungal clearance. J Leukoc Biol. 2016;100(3):1-8.

Lim PS, Sutton CR, Rao S. Protein kinase C in the immune system: from signalling to chromatin regulation. Immunology. 2015;146:508-22.

Lin H, Xiao Y, Chenetal G. HMG-CoA reductase inhibitor simvastatin suppresses Toll-like receptor 2 ligand-induced activation of nuclear factor kappa $\mathrm{B}$ by preventing RhoA activation in monocytes from rheumatoid arthritis patients. Rheumatol Int. 2010;31(11):1451-8.

Liou J, Kim ML, Heo WD, Jones JT, Myers JW, Ferrell JE Jr, Meyer T. STIM is a $\mathrm{Ca}^{2+}$ sensor essential for $\mathrm{Ca}^{2+}$-store-depletion-triggered $\mathrm{Ca}^{2+}$ influx. Curr Biol. 2005;15(13):1235-41.

Liu Y, Song R, Gao Y, Li Y, Wang S, Liu HY, Wang Y, Hu $\mathrm{YH}$, Shu HB. Protein kinase $\mathrm{C}-\delta$ negatively regulates $\mathrm{T}$ cell receptor-induced NF- $\kappa \mathrm{B}$ activation by inhibiting the assembly of CARMA1 signalosome. J Biol Chem. 2012;287(24):20081-7.

Liu X, Berry CT, Ruthel G, Madara JJ, MacGillivray K, Gray CM, Madge LA, McCorkell KA, Beiting DP, Hershberg U, May MJ, Freedman BD. T cell receptorinduced nuclear factor $\kappa \mathrm{B}(\mathrm{NF}-\kappa \mathrm{B})$ signaling and transcriptional activation are regulated by STIM1and orail-mediated calcium entry. J Biol Chem. 2016;291(16):8440-52.

Loegering DJ, Lennartz MR. Protein kinase C and toll-like receptor signaling. Enzyme Res. 2011;2011:537821.

Ma JS, Monu N, Shen DT, Mecklenbräuker I, Radoja N, Haydar TF, Leitges M, Frey AB, Vukmanovic S, Radoja S. Protein kinase Cdelta regulates antigen receptor-induced lytic granule polarization in mouse CD8+ CTL. J Immunol. 2007;178(12):7814-21.

Ma J, Ding Y, Fang X, Wang R, Sun Z. Protein kinase $\mathrm{C}-\theta$ inhibits inducible regulatory $\mathrm{T}$ cell differentiation via an AKT-Foxo1/3a-dependent pathway. J Immunol. 2012;188:5337-47.

Manukyan M, Nalbant P, Luxen S, Hahn KM, Knaus UG. RhoA GTPase activation by TLR2 and TLR3 
ligands: connecting via Src to NF-kappaB. J Immunol. 2009;182(6):3522-9.

Marsland BJ, Kopf M. T-cell fate and function: PKC-h and beyond. Trends Immunol. 2008;29:179-85.

Mauri C, Menon M. Human regulatory B cells in health and disease: therapeutic potential. J Clin Invest. 2017;127(3):772-9.

McGettrick AF, Brint EK, Palsson-McDermott EM, Rowe DC, Golenbock DT, Gay NJ, Fitzgerald KA, O'Neill LA. Trif-related adapter molecule is phosphorylated by PKC \{epsilon $\}$ during Toll-like receptor 4 signaling. PNAS. 2006;103(24):9196-201.

Mérida I, Arranz-Nicolás J, Rodríguez-Rodríguez C, Ávila-Flores A. Diacylglycerol kinase control of protein kinase C. Biochem J. 2019;476(8):1205-19.

Miyamoto A, Nakayama K, Imaki H, Hirose S, Jiang Y, Abe M, Tsukiyama T, Nagahama H, Ohno S, Hatakeyama S, Nakayama KI. Increased proliferation of $\mathrm{B}$ cells and auto-immunity in mice lacking protein kinase C delta. Nature. 2002;416(6883):865-9.

Neagu M. The immune system - a hidden treasure for biomarker discovery in cutaneous melanoma. In: Makowski GS, editor. Advances in clinical chemistry, vol. 58. Burlington: Academic Press; 2012. p. 89-140.

Newton AC. Regulation of the ABC kinases by phosphorylation: protein kinase $\mathrm{C}$ as a paradigm. Biochem $\mathrm{J}$. 2003;370(2):361-71.

Newton AC. Protein kinase C: perfectly balanced. Crit Rev Biochem Mol Biol. 2018;53(2):208-30.

$\mathrm{Ng}$ Yan Hing JD, Desjardins M, Descoteaux A. Proteomic analysis reveals a role for protein kinase $\mathrm{C}$-alpha in phagosome maturation. Biochem Biophys Res Commun. 2004;319(3):810-6.

Nishizuka Y. Protein kinase $\mathrm{C}$ and lipid signaling for sustained cellular responses. FASEB J. 1995;9:484.

Packard TA, Cambier JC. B lymphocyte antigen receptor signaling: initiation, amplification, and regulation. F1000 Prime Rep. 2013;5:40.

Palaniyandi SS, Sun L, Ferreira JC, Mochly-Rosen D. Protein kinase $\mathrm{C}$ in heart failure: a therapeutic target? Cardiovasc Res. 2009;82(2):229-39.

Parihar A, Eubank TD, Andrea I, Doseff AI. Monocytes and macrophages regulate immunity through dynamic networks of survival and cell death. J Innate Immun. 2010;2(3):204-15.

Park CH, Kim KT. Apoptotic phosphorylation of histone $\mathrm{H} 3$ on Ser-10 by protein kinase C $\delta$. PLoS One. 2012;7:e44307.

Patel H, Shaw SG, Shi-Wen X, Abraham D, Daryll M, Baker DM, Janice CS, Tsui JCS. Toll-like receptors in ischaemia and its potential role in the pathophysiology of muscle damage in critical limb ischaemia. Cardiol Res Pract. 2012;2012:121237.

Pfeifhofer C, Kofler K, Gruber T, Tabrizi NG, Lutz C, Maly K, Leitges M, Baier G. Protein kinase $\mathrm{C}$ h affects $\mathrm{Ca} 2+$ mobilization and NFAT cell activation in primary mouse T cells. J Exp Med. 2003;197:1525-35.

Roos J, DiGregorio PJ, Yeromin AV, Ohlsen K, Lioudyno M, Zhang S, Safrina O, Kozak JA, Wagner SL, Cahalan MD, Veliçelebi G, Stauderman KA. STIM1, an essen- tial and conserved component of store-operated $\mathrm{Ca}^{2+}$ channel function. J Cell Biol. 2005;169(3):435-45.

Saijo K, Mecklenbräuker I, Santana A, Leitger M, Schmedt C, Tarakhovsky A. Protein kinase C beta controls nuclear factor kappaB activation in B cells through selective regulation of the IkappaB kinase alpha. J Exp Med. 2002;195:1647-52.

Salek-Ardakani S, So T, Halteman BS, Altman A, Croft M. Protein kinase Ch controls Th1 cells in experimental autoimmune encephalomyelitis. J Immunol. 2005;175(11):7635-41.

Salzer E, Santos-Valente E, Keller B, Warnatz K, Boztug $\mathrm{K}$. Protein kinase $\mathrm{C} \delta$ : a gatekeeper of immune homeostasis. J Clin Immunol. 2016;36(7):631-40.

Sarvaria A, Madrigal JA, Saudemont A. B cell regulation in cancer and anti-tumor immunity. Cell Mol Immunol. 2017;14(8):662-74.

Saurin AT, Durgan J, Cameron AJ, Faisal A, Marber MS, Parker PJ. The regulated assembly of a PKCepsilon complex controls the completion of cytokinesis. Nat Cell Biol. 2008;10(8):891-901.

Shibolet O, Giallourakis C, Rosenberg I, Mueller T, Xavier RJ, Podolsky DK. AKAP13, a RhoA GTP a sespecific guanine exchange factor, is a novel regulator of TLR2 signaling. J Biol Chem. 2007;282(48):35308-17.

Shinohara H, Yasuda T, Aiba Y, Sanjo H, Hamadate M, Watarai H, Sakurai H, Kurosaki T. PKC b regulates BCR-mediated IKK activation by facilitating the interaction between TAK1 and CARMA1. J Exp Med. 2005;202:1423-31.

Shinohara H, Maeda S, Watarai H, Kurosaki T. IkappaB kinase $b$-induced phosphorylation of CARMA1 contributes to CARMA1 Bcl10 MALT1 complex formation in B cells. J Exp Med. 2007;204:3285-93.

Smith-Garvin JE, Koretzky GA, Jordan MS. T cell activation. Annu Rev Immunol. 2009;27:591-619.

Snider AJ, Orr Gandy KA, Obeid LM. Sphingosine kinase: role in regulation of bioactive sphingolipid mediators in inflammation. Biochimie. 2010;92(6):707-15.

Stephenson R, Singh A. Drug discovery and therapeutic delivery for the treatment of B and T cell tumors. Adv Drug Deliv Rev. 2017;114:285-300.

Taher TE, Bystrom J, Ong VH, Isenberg DA, Renaudineau Y, Abraham DJ, Mageed RA. Intracellular B lymphocyte signalling and the regulation of humoral immunity and autoimmunity. Clin Rev Allergy Immunol. 2017;53(2):237-64.

Tan SL, Parker PJ. Emerging and diverse roles of protein kinase $\mathrm{C}$ in immune cell signalling. Biochem $\mathrm{J}$. 2003;376(Pt 3):545-52.

Tan SL, Zhao J, Bi C, Chen XC, Hepburn DL, Wang J, Sedgwick JD, Chintalacharuvu SR, Na S. Resistance to experimental autoimmune encephalomyelitis and impaired IL-17 production in protein kinase $\mathrm{C}$ h-deficient mice. J Immunol. 2006;176:2872-9.

Teixeiro E, Daniels MA, Hamilton SE, Schrum AG, Bragado R, Jameson SC, Palmer E. Different T cell receptor signals determine $\mathrm{CD} 8+$ memory versus effector development. Science. 2009;323:502-5. 
Thome M, Charton JE, Pelzer C, Hailfinger S. Antigen receptor signaling to NF-kappaB via CARMA1, BCL10, and MALT1. Cold Spring Harb Perspect Biol. 2010;2(9):a003004.

Tsui C, Martinez-Martin N, Gaya M, Maldonado P, Llorian M, Legrave NM, Rossi M, MacRae JI, Cameron AJ, Parker PJ, Leitges M, Bruckbauer A, Batista FD. Protein kinase C-b dictates B cell fate by regulating mitochondrial remodeling, metabolic reprogramming, and heme biosynthesis. Immunity. 2018;48:1144-59.

von Essen MR, Kongsbak M, Levring TB, Hansen AK, Boding L, Lauritsen JP, Woetmann A, Baier G, Ødum $\mathrm{N}$, Bonefeld CM, Geisler C. PKC- $\theta$ exists in an oxidized inactive form in naive human $\mathrm{T}$ cells. Eur $\mathrm{J}$ Immunol. 2013;43:1659-66.

von Knethen A, Soller M, Tzieply N, Weigert A, Johann AM, Jennewein C, Köhl R, Brüne B. PPARgamma1 attenuates cytosol to membrane translocation of PKC alpha to desensitize monocytes/macrophages. J Cell Biol. 2007;176(5):681-94.

Wachowicz K, Hermann-Kleiter N, Meisel M, Siegmund $\mathrm{K}$, Thuille N, Baier G. Protein kinase $\mathrm{C} \theta$ regulates the phenotype of murine CD4+ Th17 cells. PLoS One. 2014;9:e96401.

Yang CS, Lee JS, Song CH, Hur GM, Lee SJ, Tanaka S, Akira S, Paik TH, Jo EK. Protein kinase C zeta plays an essential role for Mycobacterium tuberculosis induced extracellular signal-regulated kinase 1/2 activation in monocytes/macrophages via Toll-like receptor 2. Cell Microbiol. 2007;9(2):382-96.

Yokosuka T, Saito T. The immunological synapse, TCR microclusters, and $\mathrm{T}$ cell activation. Curr Top Microbiol Immunol. 2010;340:81-107.

Yokosuka T, Kobayashi W, Sakata-Sogawa K, Takamatsu M, Hashimoto-Tane A, Dustin ML, Tokunaga M, Saito T. Spatiotemporal regulation of T cell costimulation by TCR-CD28 microclusters and protein kinase C $\theta$ translocation. Immunity. 2008;29:589-601.

Zanin-Zhorov A, Ding Y, Kumari S, Attur M, Hippen KL, Brown Blazar BR, Abramson SB, Lafaille JJ, Dustin ML. Protein kinase $\mathrm{C}$-h mediates negative feedback on regulatory T cell function. Science. 2010;328:372-6.

Zhou X, Yang W, Li J. Ca2+- and protein kinase C-dependent signaling pathway for nuclear factor kappa B activation, inducible nitric-oxide synthase expression, and tumor necrosis factor-alpha production in lipopolysaccharide-stimulated rat peritoneal macrophages. J Biol Chem. 2006;281(42):31337-47.

Zuidscherwoude M, Dunlock VE, van den Bogaart G, van Deventer SJ, van der Schaaf A, van Oostrum J, Goedhart J, In't Hout J, Hämmerling GJ, Tanaka S, Nadler A, Schultz C, Wright MD, Adjobo-Hermans MJW, van Spriel AB. Tetraspanin microdomains control localized protein kinase $\mathrm{C}$ signaling in B cells. Sci Signal. 2017;10(478):eaag2755.

Open Access This chapter is licensed under the terms of the Creative Commons Attribution 4.0 International License (http://creativecommons.org/licenses/by/4.0/), which permits use, sharing, adaptation, distribution and reproduction in any medium or format, as long as you give appropriate credit to the original author(s) and the source, provide a link to the Creative Commons license and indicate if changes were made.

The images or other third party material in this chapter are included in the chapter's Creative Commons license, unless indicated otherwise in a credit line to the material. If material is not included in the chapter's Creative Commons license and your intended use is not permitted by statutory regulation or exceeds the permitted use, you will need to obtain permission directly from the copyright holder.

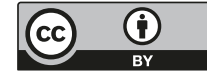

